
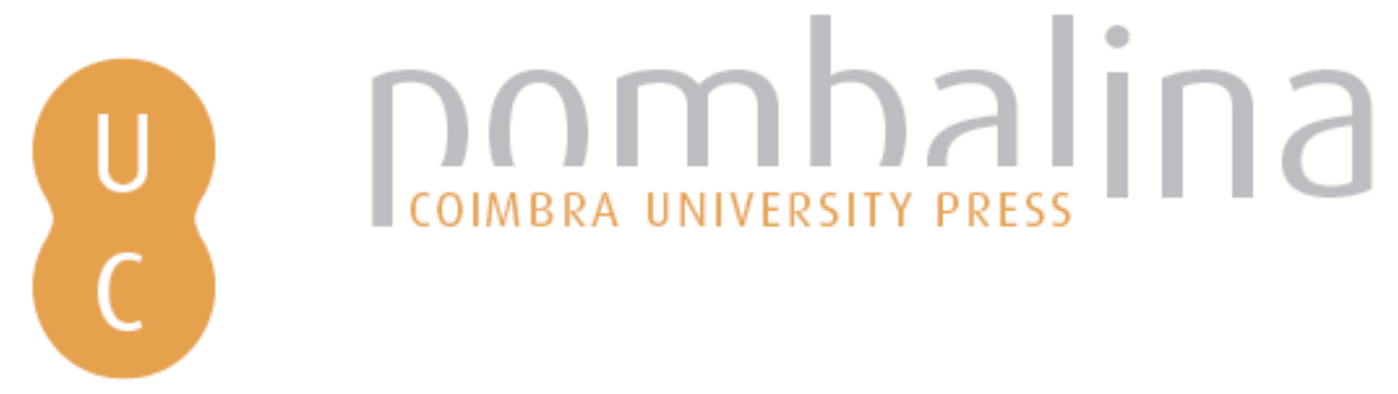

\title{
Wildland urban interface assessment and prediction in relation to land use and land cover changes: the Portuguese case study
}

Autor(es): $\quad$ Tonini, Marj; Amato, Federico; Parente, Joana; Pereira, Mário G.

Publicado por: Imprensa da Universidade de Coimbra

URL

persistente: URI:http://hdl.handle.net/10316.2/44613

DOI: $\quad$ DOI:https://doi.org/10.14195/978-989-26-16-506_96

Accessed : $\quad$ 26-Apr-2023 11:55:38

A navegação consulta e descarregamento dos títulos inseridos nas Bibliotecas Digitais UC Digitalis, UC Pombalina e UC Impactum, pressupõem a aceitação plena e sem reservas dos Termos e Condições de Uso destas Bibliotecas Digitais, disponíveis em https://digitalis.uc.pt/pt-pt/termos.

Conforme exposto nos referidos Termos e Condições de Uso, o descarregamento de títulos de acesso restrito requer uma licença válida de autorização devendo o utilizador aceder ao(s) documento(s) a partir de um endereço de IP da instituição detentora da supramencionada licença.

Ao utilizador é apenas permitido o descarregamento para uso pessoal, pelo que o emprego do(s) título(s) descarregado(s) para outro fim, designadamente comercial, carece de autorização do respetivo autor ou editor da obra.

Na medida em que todas as obras da UC Digitalis se encontram protegidas pelo Código do Direito de Autor e Direitos Conexos e demais legislação aplicável, toda a cópia, parcial ou total, deste documento, nos casos em que é legalmente admitida, deverá conter ou fazer-se acompanhar por este aviso. 


\section{ADVANCES IN}

\section{FOREST FIRE RESEARCH}

\section{8}

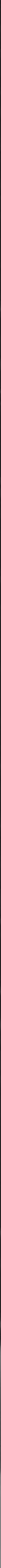




\title{
Wildland Urban Interface assessment and prediction in relation to land use and land cover changes. The Portuguese case study
}

\author{
Marj Tonini $^{1 *}$; Federico Amato ${ }^{1}$; Joana Parente ${ }^{3}$; Mário G. Pereira ${ }^{2,3}$ \\ ${ }^{1}$ Institute of Earth Surface Dynamics, Faculty of Geosciences and Environment, University of \\ Lausanne, Géopolis Building, UNIL Mouline - 1015 Lausanne, Switzerland, \\ \{marj.tonini@unil.ch*,federico.amato@unibas.it\} \\ ${ }^{2}$ Centro de Investigação e Tecnologias Agroambientais e Biológicas, Universidade de Trás-os- \\ Montes e Alto Douro, Quinta de Prados, 5000-801 Vila Real, Portugal, \{joanaparente@utad.pt; \\ gpereira@utad.pt\} \\ ${ }^{3}$ Instituto Dom Luiz, Faculdade de Ciências da Universidade de Lisboa, Lisboa, Portugal, \\ \{gpereira@utad.pt\}
}

\begin{abstract}
The Wildland-Urban Interface (WUI) refers to the zone of transition between wildlands and human development. Its spatio-temporal evolution is strongly influenced by land use/land cover changes (LULCC). In Mediterranean countries, WUI represents the most prone area for human-caused wildfires, and is, at present, a central focus of wildfire policy. Traditionally, WUI maps rest on the measurement of the distances among human settlements and wildlands. This methodology is effective to produce detailed maps and to give precise indications, but it is rigid and needs to pre-define fixed parameters. To overcome this uncertainty, we introduce a LULCC simulation model based on Machine Learning approach, allowing to produce prediction maps for the land cover classes related to the WUI. Finally, Fuzzy Set Theory is used to develop continuous non-categorical maps expressing the possibility of being part of this interface. The proposed methodology has been applied to the case study of Portugal, and considers the land covers referred to different epochs $(1990,2000$, and 2012). Both a classical geospatial analyses and an innovative simulation approach were adopted: as result we obtained traditional maps of the WUI for the different investigated periods ("hard" boundaries), and a fuzzy WUI map ("soft" prediction) for the year 2030. The framework proposed in this paper correctly identifies the areas belonging to this interface, providing useful information for wildfiresprevention policies.
\end{abstract}

Keywords: WUI, land use / land cover changes, simulation model, GIS, Machine Learning

\section{Introduction}

The Wildland-Urban Interface (WUI) is known as the area where structures and other human development meet or intermingle with wildland and rural area (USDI and USDA 2001). Humancaused wildfires have a very high probability of starting and spreading within the WUI, representing a main hazard for people, houses and other infrastructures. For these reasons, WUI mapping became a key tool to identify areas where to concentrate financial and technical resources for fire protection and prevention actions. Anthropogenic and environmental features, such as urban growth, fragmentation of rural areas, deforestation and land use / land cover changes (LULCC), shaped the WUI's extension. In Portugal, significant LULCC occurred in the last decades in response to trends associated with the socioeconomic development, such as rural abandonment, migration, ageing of population (Van Doorn and Bakker 2007; Diogo and Koomen 2012; Pereira et al. 2014). In the present study, authors consider LULCC for the period 1990 - 2012 as base data to elaborate WUI maps of Continental Portugal and to assess the evolution of its extension. Afterwards, an innovative approach resting on LULCC simulation model is introduced; this allowed to make prediction on the future extension of the land cover classes related to the WUI in the following two decades (up to 2030). 
Finally, the fuzzy set theory has been used both to overly urban with rural scenarios and to elaborate a fuzzy WUI possibility map for the year 2030. The main novelty of this method is that it escapes from the definition of rigid boundaries with their dependence on predefined parameters.

\section{Materials and methods}

\subsection{Study area: Portugal}

Mainland Portugal (Fig.1) covers the western coast of the Iberian Peninsula with a land surface of $89,000 \mathrm{~km}^{2}$ and an altitude ranging from sea level to about $2000 \mathrm{~m}$ in the north-central region.

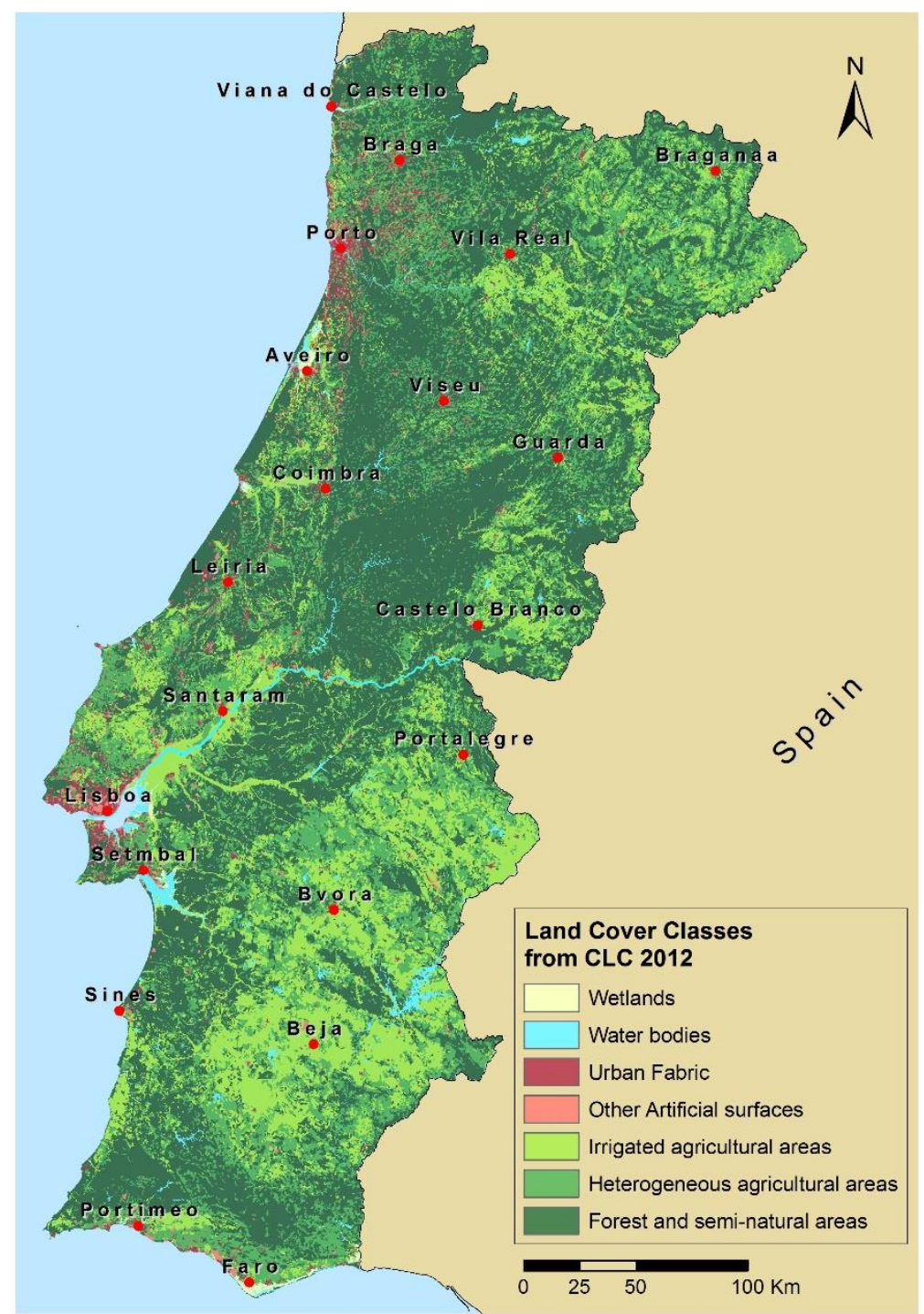

Figure 1 - Continental Portugal with main cities and land cover based on the second level of CORINE land cover (CLC) inventory 2012

The climate is temperate and typical Mediterranean. Vegetation grows in the spring season, while it experiences hydric and thermal stress during the summer months (Amraoui et al. 2015), when most burnt areas (about 90\%) are reported. Forests are predominant in the northern half of the country, while in the southern part prevail agricultural lands and scrub vegetation. Weather and climate are responsible for about two-thirds of the total annual burnt area inter-annual variability, which results unevenly distributed in space and in time within the country (Tonini et al., 2018). 


\subsection{Data acquisition and processing}

Information on land use / land cover came from the CORINE Land Cover (CLC) inventory, provided by European Environment Agency (https://land.copernicus.eu/pan-european/corine-landcover). CLC inventory is organised in different classes articulated over three levels and are currently available for four periods $(1990,2000,2006$, and 2012) with a minimum time consistency of plus/minus one year and a minimum mapping unit of 25 hectares. For the present purpose, CLC maps have been reclassified with reference to the second level as reported in Table 1.

Table 1 - Land cover classification based on the second level of the CORINE Land Cover (CLC) nomenclature.

\begin{tabular}{|l|l|}
\hline Proposed Classification & CLC Nomenclature (Level 2) \\
\hline Urban fabric & Urban fabric \\
\hline \multirow{4}{*}{ Other artificial surfaces } & Industrial, commercial and transport units \\
\cline { 2 - 2 } & Mine, dump and construction sites \\
\cline { 2 - 2 } & Artificial, non-agricultural vegetated areas \\
\hline \multirow{3}{*}{ Irrigated agricultural areas } & Arable land \\
\cline { 2 - 2 } & Permanent crops \\
\cline { 2 - 2 } & Pastures \\
\hline Heterogeneous agricultural areas & Heterogeneous agricultural areas \\
\hline \multirow{3}{*}{ Forest and semi-natural areas } & Forest \\
\cline { 2 - 2 } & Shrub and/or herbaceous vegetation associations \\
\cline { 2 - 2 } & Open spaces with little or no vegetation \\
\hline \multirow{2}{*}{ Wetlands } & Inland wetlands \\
\cline { 2 - 2 } & Coastal wetlands \\
\hline \multirow{2}{*}{ Water bodies } & Inland waters \\
\cline { 2 - 2 } & Marine waters \\
\hline
\end{tabular}

A number of driving variables were selected to calibrate the simulation model. Driving forces are defined as those factors that cause LULCC and having a marked association with the nature of the change (Meyfroidt, 2016). In the present study, we considered the following 17 driving variables: digital elevation model (DEM) and derivatives (slope, aspect), provided by the European Environment Agency (EEA) under the framework of the Copernicus programme; agricultural and population census data, derived from the Portuguese National Institute of Statistics (Portal do Instituto Nacional de Estatística n.d.); distance from primary roads and from the cities with more than 50.000 inhabitants coming from the Open Street Map Database (https://www.openstreetmap.org); soil thickness, ph, texture and ecological values were made available from EPIC WebGIS, an interactive spatial data infrastructure which provides georeferenced cartography at Portuguese national scale. Supplementary variables were finally derived from a change detection analysis between the inputs of CLC maps. All data were reprocessed on a regular grid (i.e. raster format) with a spatial resolution of 500 by 500 meters.

\subsection{WUI mapping}

A geoprocessing workflow based on a GIS analysis was implemented to produce WUI's maps for different periods, corresponding the available CLC inventories. Subsequently, an approach based on LULCC simulation models was designed to elaborate scenarios allowing to predict WUI extension for 2030.

\subsubsection{Geoprocessing workflow}

A geoprocessing workflow was developed and implemented into a mode builder, a specific application available in ArcGIS ${ }^{\mathrm{TM}}$ software environment and allowing to string together sequences of

Advances in Forest Fire Research 2018 - Page 872 
geoprocessing tools. This approach have the advantage of automating the operations and making them reproducible. The specific objective is to extract the intersection areas between a buffer around the urban fabric and the area resulting from the sum of the forest and semi-natural areas plus the heterogeneous agricultural areas, which denote the wildlands. A buffer width of $1 \mathrm{~km}$, corresponding to two times the spatial resolution of CLC inventories, was retained. Different studies in other countries applied similar distance-values for WUI mapping (Radeloff et al. 2005; Vilar et al. 2016) and, at the same time, we estimated that this buffer is sufficiently large to avoid bias in the results due to the base cartographic map unit. As regards the methodology and the choice of the CLC classes to define the WUI, we refer to the work of Tonini et al. (2018), with the difference that in the present study authors include only the continuous and discontinuous urban fabric in the definition of the urban area.

\subsubsection{Simulation model}

A future scenario for LULCC was computed for the year 2030 using a spatially explicit inductive method, based on the transitions between two observed land covers (CLC1990-CLC2000 and CLC2000 - CLC2012) (Fig. 2). The transition potential for the subsequent period (i.e. 2012 for the calibration phase and 2030 for the simulation phase) was computed using Multilayer Perceptron (MLP), a popular Machine Learning algorithm resting on feedforward artificial neural network, given as input the described driving variables. The real quantities of changes, measured through a change detection, were then spatially allocated based on MLP outputs. The model was validated via Kappa statistics, by comparing the resulting 2012-simulation map with the reference CLC map for the same year. Once calibrated the model, the resulting best parameters were retained to elaborate the future land cover scenarios for the year 2030, allocating the expected changes via a Markov Chain procedure. Hence, the resulting scenarios toward the wildlands and the urban areas were used to predict the future WUI extension. To this end, fuzzy set theory was applied to produce fuzzy maps expressing the possibility of each pixel of experiencing a transition toward wildland coverages and of being in a distance from urban areas. These maps were then overlapped through joint membership fuzzy functions, resulting in a map expressing the possibility of an area to belong to the WUI in 2030. This procedure, although quite complex, is extremely robust and has the advantage of not relying on expert knowledge inputs. An exhaustive explanation of the methodology and obtained results can be found on Amato et al. (2018).

\subsubsection{Model validation}

To validate the ability of the MLP to correctly predict the land cover changes, the real transition matrix measured for the period 2000-2012 was used to model change demand. The result was a land cover simulation for the year 2012 which was compared with the reference map (i.e. CLC2012) obtaining an overall Kappa of 0.8227. This value expresses a high capacity of the model to simulate the real-occurred land cover transitions. The validation of the obtained possibility maps for WUI was done via the relative operating characteristic (ROC). To this end, we selected a dataset of point falling inside the WUI2012 map ("presence" observation), than divided in training/testing subset. Furthermore, randomly chosen pseudo-absence points were added to both the training and testing sets. 
Calibration

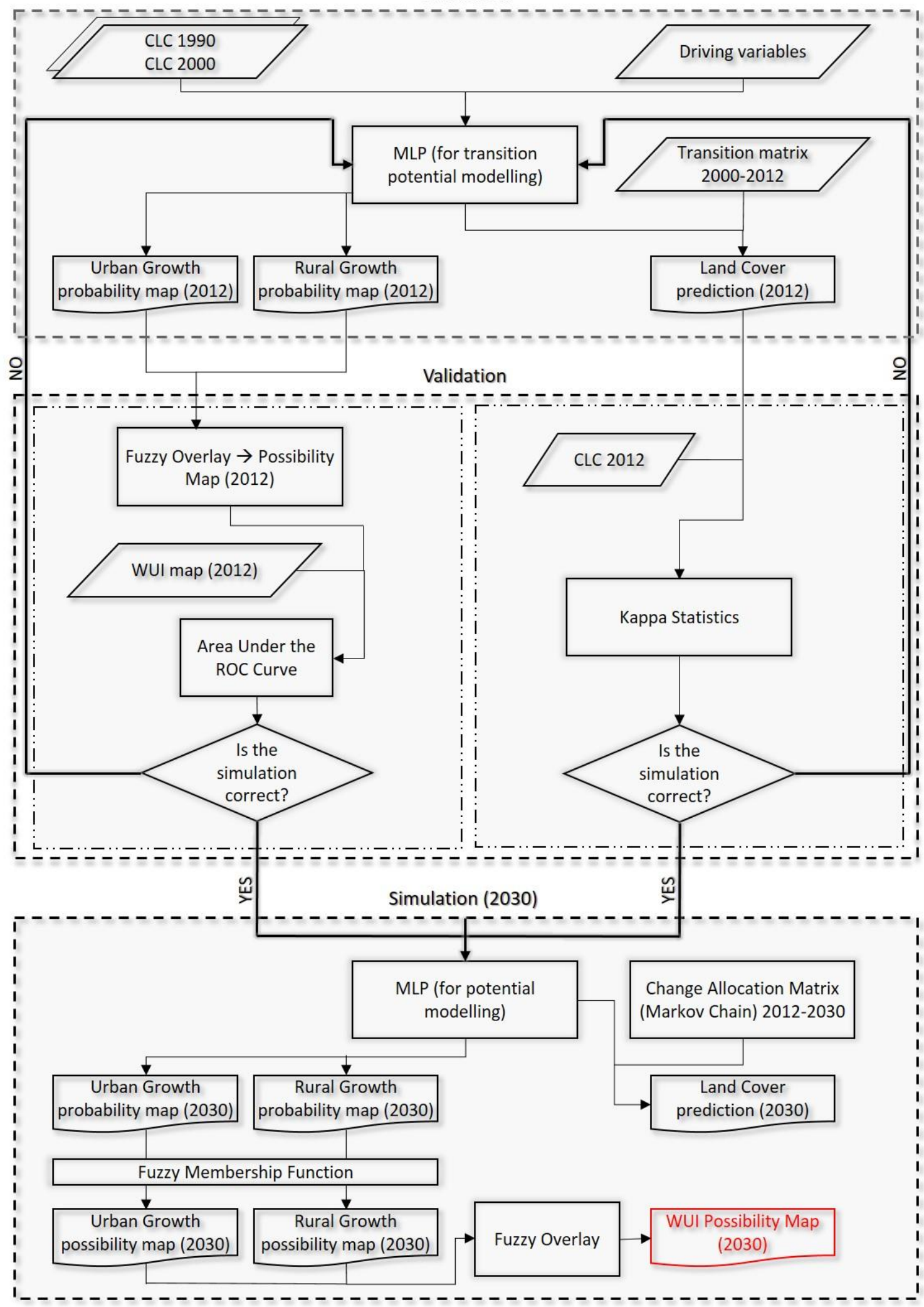

Figure 2 - Flowchart of the entire procedure including the land use / land cover changes simulation model and the fuzzy set theory allowing to produce the Wildland-Urban Interface (WUI) possibility map for 2030 (CLC=CORINE Land Cover; MLP= Multilayer Perceptron) 


\section{Results}

The proposed methodology allowed to produce maps of the WUI for different periods (1990, 2000, and 2012) and to predict both the "hard" boundaries and the "fuzzy" WUI map (i.e. "soft prediction") for the year 2030 (Fig. 3 and Fig. 4).

Globally, WUI increased from about $690 \times 10^{3}$ ha in 1990 up to about $1050 \times 10^{3}$ ha in 2012 (Table 2 ). This growth is more pronounced in the north-west and along the coast, mainly due to the urban growth. From our analyses, WUI is not expected to increase further in the next 20 years.

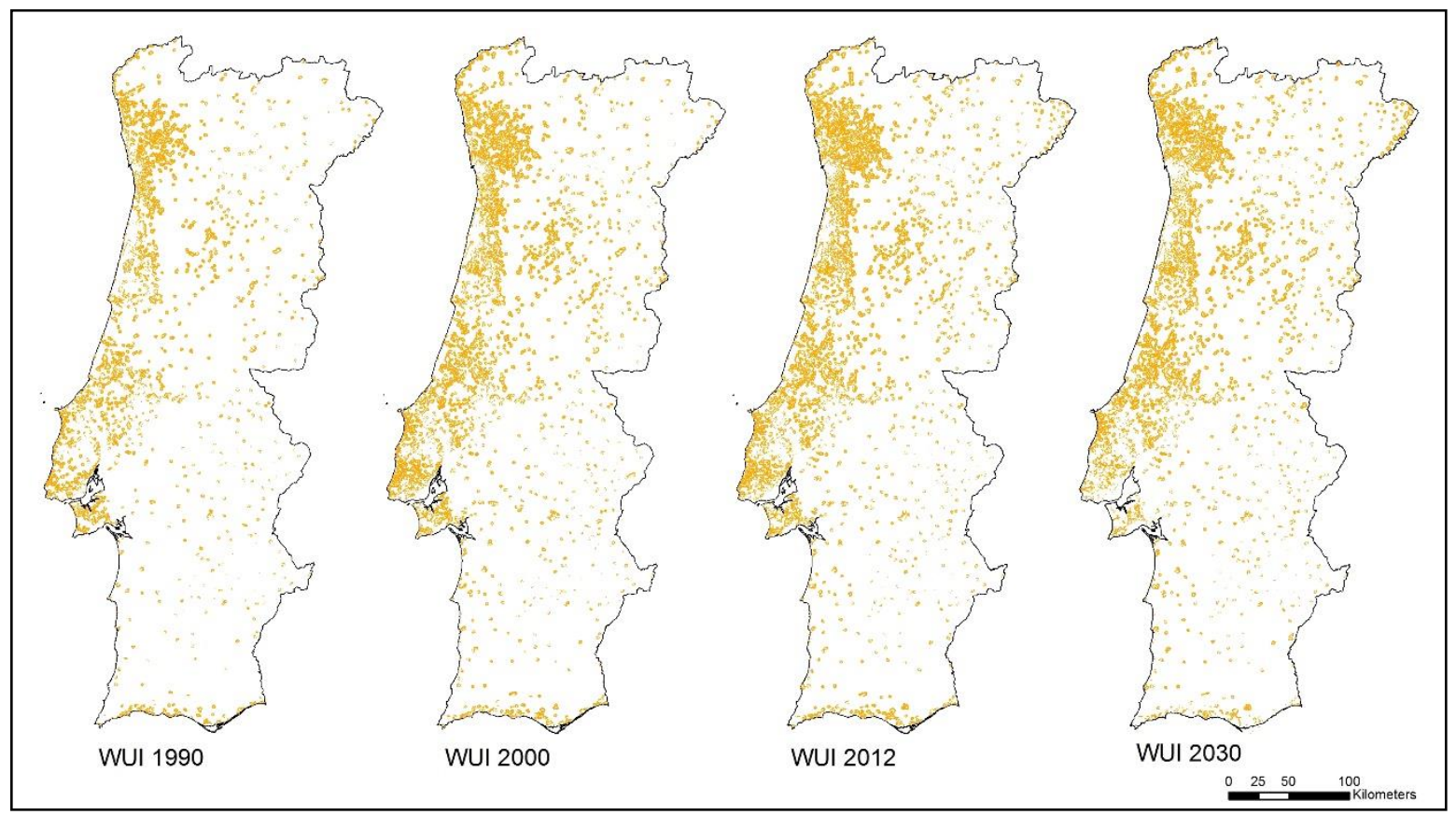

Figure 3 - Maps of the Wildland-Urban Interface (WUI) in Portugal estimated for the different periods of investigation $(1990,2000,2012,2030)$

From 1990 to 2012 the urban areas and other artificial surfaces registered an increase in each frame period in comparison to the previous one, face of a decrease of the irrigated agricultural areas. This behaviour is more noticeable from 1990 to 2000 and less in the last frame period. The model predicts a slower growth of the urban area from 2012 to 2030 than it was during the two previous frame periods (1990 - 2000 and, 2000 - 2012). As regards the wildlands, both the heterogeneous agricultural and the forest and semi natural areas stay almost unchanged during the entire simulation period.

Table 2 - Area (in hectares) of Wildland-Urban Interface (WUI) and different land cover classes affecting the WUI for each investigated period (on the top). For each frame period, net percentage changes are computed relative to the total area of each classes in the later period (on the bottom).

\begin{tabular}{|c|c|c|c|c|c|c|}
\hline Year & WUI & $\begin{array}{c}\text { Urban } \\
\text { area }\end{array}$ & $\begin{array}{c}\text { Other } \\
\text { artificial } \\
\text { surfaces }\end{array}$ & $\begin{array}{c}\text { Irrigated } \\
\text { agricultural } \\
\text { areas }\end{array}$ & $\begin{array}{c}\text { Heterogeneous } \\
\text { agricultural } \\
\text { areas }\end{array}$ & $\begin{array}{c}\text { Forest and } \\
\text { semi natural } \\
\text { areas }\end{array}$ \\
\hline 1990 & 688989 & 133704 & 35630 & 1975871 & 2371018 & 4274600 \\
\hline 2000 & 966972 & 214379 & 67432 & 1905894 & 2344481 & 4252424 \\
\hline 2012 & 1049825 & 241822 & 92749 & 1811715 & 2349977 & 4264167 \\
\hline 2030 & 1013235 & 283900 & 133543 & 1699367 & 2355895 & 4287690 \\
\hline $\begin{array}{l}\text { Frame } \\
\text { period }\end{array}$ & \multicolumn{7}{|c|}{ Net \% of changes } \\
\hline $1990-2000$ & $28.75 \%$ & $37.63 \%$ & $47.16 \%$ & $-3.67 \%$ & $-1.13 \%$ & $-0.52 \%$ \\
\hline $2000-2012$ & $7.89 \%$ & $11.35 \%$ & $27.30 \%$ & $-5.20 \%$ & $0.23 \%$ & $0.28 \%$ \\
\hline $2012-2030$ & $-3.61 \%$ & $14.82 \%$ & $30.55 \%$ & $-6.61 \%$ & $0.25 \%$ & $0.55 \%$ \\
\hline
\end{tabular}


The WUI fuzzy map (Fig. 4) predicts a scenario for the year 2030, expressed in terms of possibility for an area of belonging to the WUI. The tests performed for validation (i.e. Kappa statistics and ROC curves) demonstrate the correctness and good performance of the proposed model. It results that the highest WUI extension will take place in the areas enclosed by Braga, Porto, Aveiro and Vila Real, in the north-western part of Portugal, with a spatial contiguity along the coast up to Lisbon and crossing the city of Coimbra. In the Centro Region, nearby the city of Viseu, we can observe another highly predisposed WUI area. The growing peri-urban fringes probably drove this trend. In the southern part of the country, we can observe scattered hotspot for WUI areas, extending in the mountainous region towards the interior, most likely caused by the progressive abandonment of agricultural activities and the consequent spreading of the forest in these areas. WUI will probably also extend along the coastline in the Faro Region, caused by the expansion here of tourism-led developments.

\section{Conclusions}

Obtained results highlight the effectiveness of the proposed framework in identifying the WUI through a flexible approach, which combine a LULCC simulation model with the fuzzy set theory. The main objective is to avoid the rigid definition of boundaries rising from the classical binary classification methods. In this sense, fuzzy set theory offers a solid mathematical background on which solve the issue of labelling each pixel as belonging or not to the WUI through the assignation to each pixel of a degree of possibility of being part of this interface.

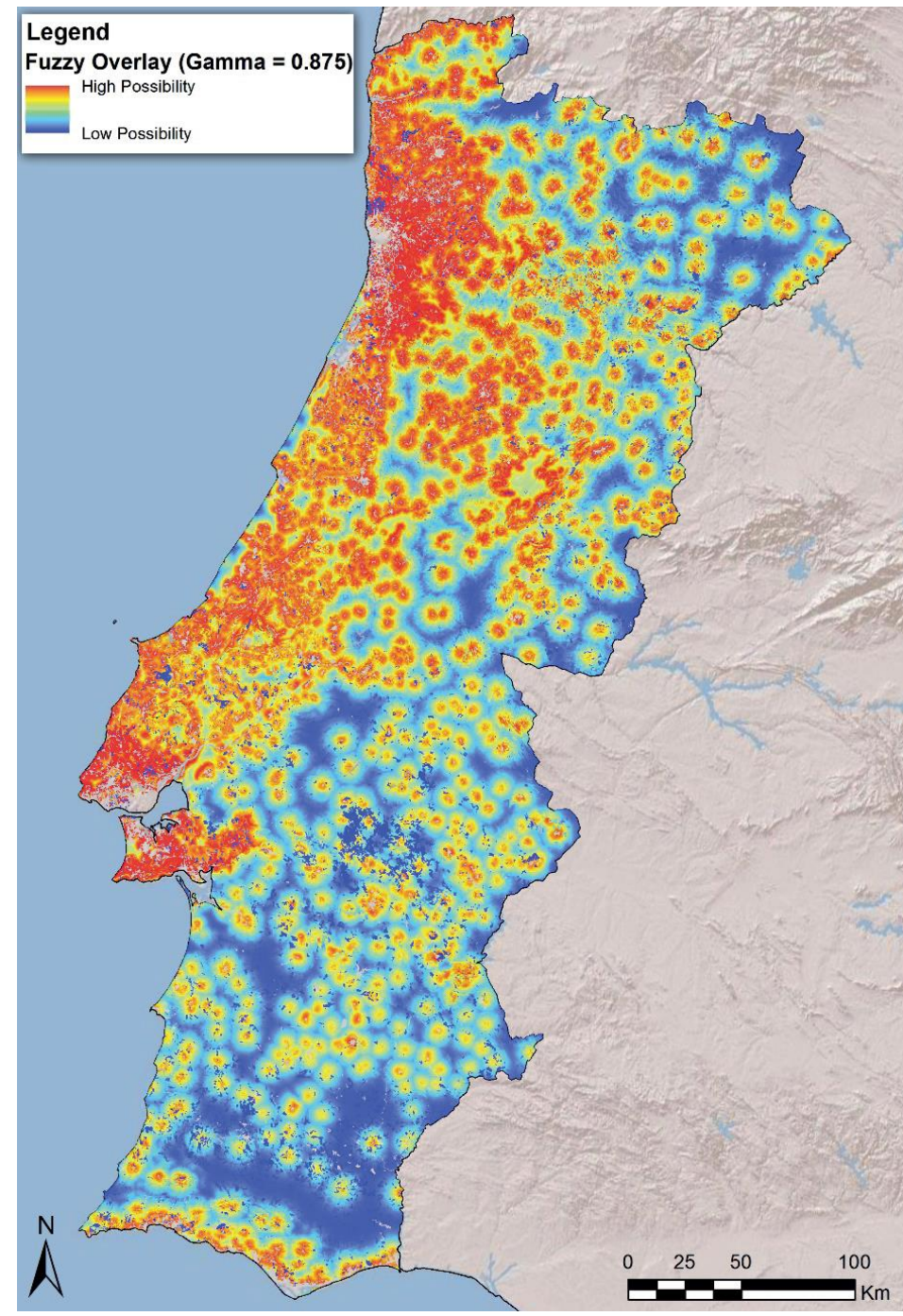

Fig. 4 - Wildland-urban interface (WUI) fuzzy map for the year 2030 


\section{References}

Amato F, Tonini M, Murgante B, Kanevski M (2018) Fuzzy definition of Rural Urban Interface: An application based on land use change scenarios in Portugal. Environmental Modelling \& Software 104, 171-187.

Amraoui M, Pereira MG, DaCamara CC, Calado TJ (2015) Atmospheric conditions associated with extreme fire activity in the Western Mediterranean region. Science of the Total Environment 524, $32-39$.

Diogo V, Koomen E (2012) Land-Use Change in Portugal, 1990-2006: Main Processes and Underlying Factors. Cartographica: The International Journal for Geographic Information and Geovisualization 47, 237-249.

Pereira MG, Aranha J, Amraoui M (2014) Land cover fire proneness in Europe. Forest Systems 23, 598-610.

Radeloff VC, Hammer RB, Stewart SI, Fried JS, Holcomb SS, McKeefry JF (2005) The wildlandurban interface in the United States. Ecological applications 15, 799-805.

Tonini M, Pereira MG, Parente J, Orozco CV , (2017). Evolution of forest fires in Portugal: from spatiotemporal point events to smoothed density maps, Natural Hazards 85, 1489-1510

Tonini M, Parente J, Pereira M (2018) Global assessment of land cover changes and rural-urban interface in Portugal. Natural Hazards Earth System Sciences 18, 1647-1664. doi:10.5194/nhess18-1647-2018.

USDI UD of the I, USDA UD of A (2001) Urban wildland interface communities within the vicinity of federal lands that are at high risk from wildfire. Federal Register 66, 751-777.

Van Doorn AM, Bakker MM (2007) The destination of arable land in a marginal agricultural landscape in South Portugal: an exploration of land use change determinants. Landscape ecology 22, 10731087.

Vilar L, Camia A, San-Miguel-Ayanz J, Martín MP (2016) Modeling temporal changes in humancaused wildfires in Mediterranean Europe based on Land Use-Land Cover interfaces. Forest Ecology and Management 378, 68-78. 